\title{
Historiska huvudlinjer i den teknologiska utvecklingen inom jordbruket ${ }^{1}$ )
}

\author{
OLLI MAKKONEN
}

Helsingfors universitet, Institutionen för skogsbrukets nationalekonomi, Unionsgatan 40 B, 00170 Helsingfors 17, Finland.

\section{Main features of the historical development of agricultural technology}

\section{O. MAKKONEN}

University of Helsinki, Dep. of Social Economics of Forestry, Unioninkatu 40 B, SF00170 Helsinki 17.

Abstract. The upright position that man made his own upon his descent from the trees, and which enabled him to use striking weapons and tools, was the first step toward human domination of the world. A factor of still greater importance, however, was his ability to use the fire produced by lightnings and volcanic eruptions, and particularly, the invention of fire-making, which was a prerequisite for the development of the most primitive of all forms of agricultural activity, namely cultivation by clearing and burning-over woodland.

One of the turning points of the most decisive importance in man's history was the introduction of permanent agriculture. A condition for all development and civilization is a surplus of food, and this could be obtained only after the introduction of permanent agriculture. This type of agricultural activity was first taken into use in the socalled dry zone along large, never-drying rivers such as the Nile, Euphrates and Tigris, and Indus, and it was based on irrigation from its very beginning.

The fast progress of Central and Northern European civilization since the time around A.D. 1000 as well as the breaking through of techniques and the industrial revolution, which came much later, were principally based on three important factors. First, within the temperate region, agricultural activities could be based rather safely on natural rains, which meant much less work as compared with agricultural activities based on irrigation. Second, the heavy turning plow was invented. In design it was more or less similar to the plows used in our time, and this invention made it possible to turn the fertile, but very heavy soils of the river and other valleys in Europe into arable land. Third, the stiff wooden hames were invented, which meant a $4-5$-fold increase in the horse's pulling capacity in comparison with the previous neck band system. Replacing the ox by the horse, which is much faster, made it possible for man to live in villages farther away from the fields than before, and this in turn increased the conditions for the development of civilization.

The industrial revolution, finally, made it possible to mechanize agricultural work and to increase productivity to an extent never seen before.

\footnotetext{
1) Föredrag hållet den 17. 12. 1980 i Skodsborg, Danmark vid ett seminarium arrangerat av "Nordiska Jordbruksforskarnas Förening
} 
Ett avgörande skede i människans utveckling och hennes möjligheter att försöka påverka sin miljö var att ta $i$ bruk elden. Konsten att uppgöra eld är uppenbarligen av relativt sent datum i människans långa utvecklingshistoria, men att bevara eld och använda sig av den har varit t.o.m. mycket gamla färdigheter. Elden fick man från bränder efter blixtnedslag eller ibland av träbitar som tänts eller blivit glödande efter vulkanutbrott. Elden bevarades genom att hela tiden hålla en liten brasa brinnande. Ännu under allra senaste tid har man t.ex. i Amazon flodens djunglar påträffat primitiva stammar som inte känner till konsten att uppgöra eld, och därför brinner en ständig eld i deras byar.

De gamla myterna innehåller ofta mycket allegorisk sanning. Enligt Prometheus-legenden, som först framfördes av den grekiske jordbruksdiktaren Hesiodos, stal bemälde Prometheus (namnet betyder den som tänker i förväg) elden av åskguden Zeus och skänkte den åt människorna. Rasande över att ha förlorat sitt monopol beslöt Zeus straffa människorna. Han formade av lera en underskön kvinna, gav henne en levande ande, skänkte henne ett med sigill tillslutet lerkrus och sände henne till människorna. Prometheus varnade sin bror Epimetheus (den som tänker i efterhand) för kvinnan som bar namnet Pandora. I synnerhet fick Pandoras lerkrus inte i någon händelse öppnas. Zeus fängslade i alla fall Prometheus vid en avlägsen klippa, så att han inte kunde vara sin broders väktare, och sände Pandora till Epimetheus som inte kunde motstå Pandoras frestelser utan tog henne till sin hustru. Makarna kunde inte länge stilla sin nyfikenhet utan öppnade locket till Pandoras lerkrus. Ut flög alla plågor, som sedan dess har prövat mänskligheten. Endast hoppet blev kvar. Till symboliken om Pandoras ask (lerkrus) återkommer jag senare.

Att människan klev ner från träden och tillägnade sig en upprätt ställning, som möjliggjorde användning av slagvapen och verktyg, var det första steget mot världsherravälde, men en ännu mera avgörande faktor var eldens ibruktagande. Med hjälp av eld kunde människan köra ut rovdjuren ur grottorna och göra det bekvämt för sig i dem. Med eldens hjälp höll hon sig varm, fick ljus i sin bostad och kunde börja äta kött, varigenom hennes föda på ett avgörande sätt mångfaldigades. Tack vare elden kunde hon slutligen bosätta sig i kallare trakter av jordklotet, dit hon tidigare inte haft ärende.

När människan lärde sig att göra upp eld där hon ville, fick hon i sin hand ett mäktigt vapen, varmed hon kunde påverka striden mellan skog och savann, och också ödelägga vidsträckta områden till öknar i torra zoner. Av endel ännu idag påträffade primitiva folkstammars beteendemönster kan man påvisa att människan haft flera motiv att förvandla skog till grässlätter. För det första ville hon förbättra sikten och göra det lättare att röra sig, för att lättare kunna jaga villebråd och undvika rovdjur. På de brända ytorna uppstod snabbt en frodig gräsväxt och därigenom kunde man öka populationen av jaktdugligt villebråd som använde markvegetationen till föda. Härifrån var steget inte långt till nomadernas boskapsskötsel. När jordbruk och boskapsskötsel sedan på allvar sköt fart, var sättet att skaffa betesmarker genom att bränna skog en utbredd vana överallt där människor bodde. Den primitivaste jordbruksformen var, och är ställvis ännu, att röja skogen genom bränning, kortvarigt odla den brända ytan och sedan flytta till en ny plats, således svedjeodling.

Jägar-, herde- och svedjeodlingsfolken har under tidernas lopp mycket starkt 


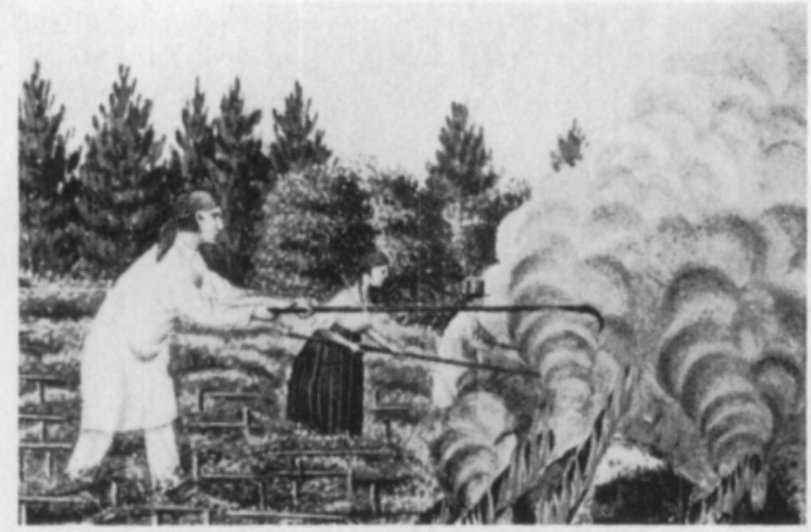

Bild 1. Svedjebränning i Finland. Målning från år 1883 .

Bild 2. Svedjeplöjning i Finland. Målning från å̀ 1883 .

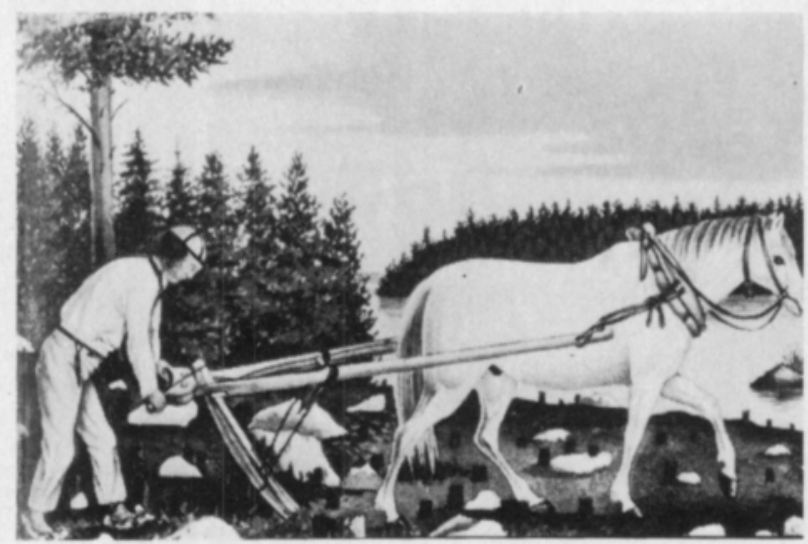

ändrat sin miljö, speciellt vad beträffar skogarnas yta och artsammansättning. Om man t.ex. i Finland inte hade idkat svedjebruk i en nära förgången tid (bilderna 1 och 2), skulle den allmänna bilden av Finlands natur vara avsevärt annorlunda än nu är fallet. Granen skulle vara betydligt allmännare, och i motsvarande grad skulle vi ha mycket mindre björk och tall, m.a.o. skulle Finland visa upp en mycket dystrare naturbild än idag.

Efter eldens ibruktagande har en av den mänskliga historiens vändpunkter, uppenbarligen en av de mest avgörande, varit övergången till ett ihållande jordbruk. Ett villkor för all utveckling och civilisation är ett överskott på näringsmedel. Så länge människan förmådde anskaffa föda endast för sig själv och sina barn hade ingen tid att tänka på någon förbättring av arbetsmetoderna eller att göra uppfinningar. Först då människan kunde producera födoämnen utöver sitt eget behov - under uppsamlings- och jakthushållningens tid lyckades det $\mathrm{i}$ allmänhet inte - kunde en del individer med stöd av detta överskott ägna sig åt att lära sig nya färdigheter och innovationer för att föra utvecklingen vidare. Det enda verkligt betydelsefulla överskottet har hittills varit den energigivande kolhydrathaltiga näring som erhållits ur sädes- och andra odlingsväxter. De överskott boskapsskötseln ger är också de i huvudsak följdverkningar av växtodlingen. En klar överproduktion har i allmänhet varit möjlig endast med stöd av ett ihållande jordbruk, således ännu inte vid svedjebruk. 


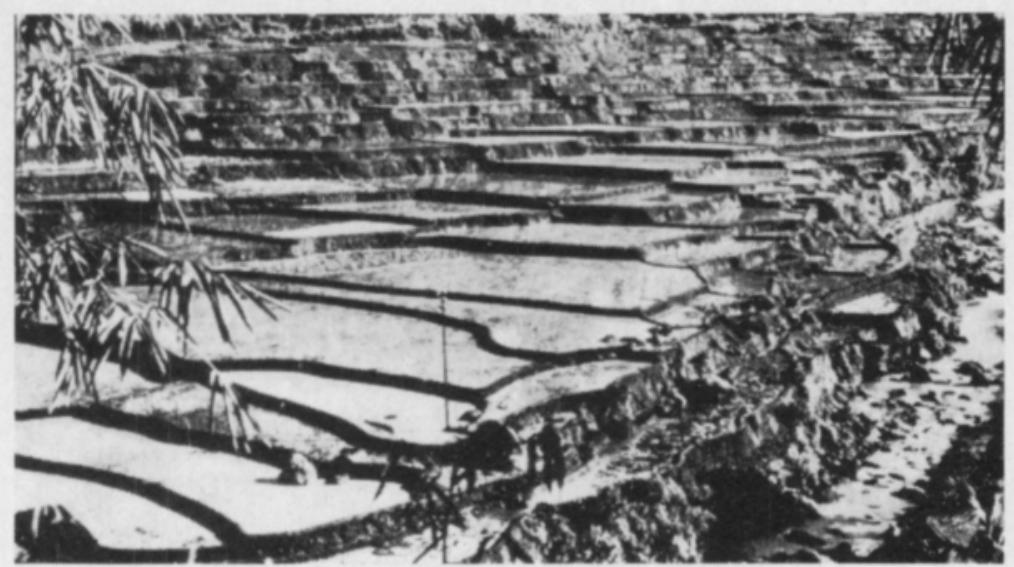

Bild 3. Sluttningar terasserade till odlingsplatåer i Indonesien.

Odling av vete och korn anses ha vidtagit i främre och mellersta Östern redan nionde årtusendet före Kristus. Vid samma tid började den jordbrukande människan hålla sig med boskap, och också förädla den genom att spara de bästa individerna för avel. Får och getter var de äldsta husdjuren, senare följda av nötboskap och åsnor. Denna nya livsstil var ägnad att öka befolkningen i rätt snabb takt, vilket i sin tur medförde att spåren som människan lämnade efter sig i sin omgivning började framträda allt tydligare.

I de äldsta områdena med ihållande jordbruk, längs Nilen, i Mesopotamien och i Indusdalen uppstod de första städerna och de första egentliga kultursamhällena. Det verkar kanske överraskande att kulturens vaggor uppstod i områden som ligger i den s. k. torra zonen där förutsättningarna för jordbruk är skäligen dåliga på grund av små regnmängder och långa torrperioder. Jordbruket grundade sig också $\mathrm{i}$ dessa områden på bevattning, som möjliggjordes av de stora, aldrig uttorkade floderna. Redan på fjärde årtusendet före Kristus fanns här blomstrande städer, välordnade samhällen, en utvecklad handslöjd och handel samt skrivkonst. Här började man också först smälta metaller och övergick från stenåldern till bronsåldern.

Upplagring och reglering av vattnet samt konstgjord bevattning medförde en betydande naturförändring. Vattnet leddes via bevattningskanaler till vidsträckta områden som annars skulle ha varit torra öknar, och för att trygga vattenförsörjningen och underlätta trafiken byggdes även stora kanaler. Sluttningarna terasserades till odlingsplatåer (bild 3), vilket i hög grad ändrade landskapet. På detta sätt förhindrades effektivt den av störtregnen förorsakade erosionen.

De samhällen som reglerade vattnet och utförde konstbevattning, eller hydraulsamhällena, som de kort kallades, behövde inte längre flytta boplats som svedjeodlarna. Detta hade ur kulturutvecklingens synpunkt synnerligen stor betydelse. Ett engång uppröjt fält var praktiskt sett röjt för tid och evighet, slammet som vattnet förde med sig gödslade jorden kontinuerligt och, som redan nämnts, faran för erosion hade undvikits. Inga stubbar utgjorde hinder, jorden var lätt att luckra, fröna såddes i raka rader och ogräset gick relativt lätt att hålla i styr. En oxdragen plog togs i bruk i Egypten och Mesopotamien på tredje årtusendet före 


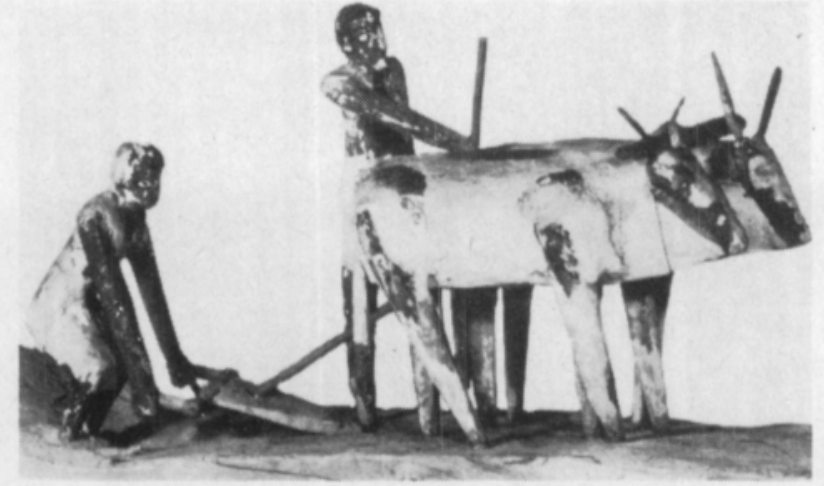

Bild 4. Miniatyrmodell av en oxdragen plog från Egypten. Tredje årtusendet $\mathrm{f} . \mathrm{Kr}$.

Kristus (bild 4). Den gjorde luckrandet av jorden betydligt effektivare och hjälpte att hålla ogräset nere. Hydraulodlingen var verkligen effektiv. Under första årtusendet före Kristus försörjde Egyptens vete- och kornodlingar 280 människor per hektar, då däremot under 16. århundradet efter Kristus fanns 36 personer per hektar i Holland, som var Europas tätast bebodda trakter och någorlunda helt och hållet uppodlat.

Den äldsta bilden av en plog försedd med såddtrattar (bild 5) härstammar från andra förkristliga årtusendet.

Hydraulodlingen var avgjort effektivare än svedjeodling, men å andra sidan fordrade den oerhört mycket arbete. Då det ännu förekommer hydraulsamhällen t.ex. i Kina och Pakistan, har man kunnat räkna ut att enbart bevattningssystemets skötsel fordrar mera tid per person än vad en europeisk jordbrukare, som förlitar sig på regnvatten, använder till hela sitt arbete. Detta är en mycket viktig skillnad, som jag återkommer till senare.

Jordbruket i främre och mellersta Östern utbredde sig åt olika håll. Redan under 6. årtusendet före Kristus bosatte sig en del sjöfararfolk, vilka lärt sig att bruka jorden, på Medelhavets stränder och öar. Nybyggarströmmen sökte sig också till Mellan-Europa, närmast längs Donaus floddal och ända fram till nuvarande Belgien. De här stammarna röjde med handredskap sina odlingar endast på en bestämd jordmån, nämligen finstrukturerad lössjord. På lössjorden växte i allmänhet glesare skog som var lättare att röja än på annan jord. De odlade sina åkrar endast så länge de hade växtkraft, och flyttade sedan vidare. Deras bostäder var stora stockhus, och därför högg de ner avsevärda mängder skog. De spår de lämnade efter sig i naturen var dock inte länge bestående.

Redan före år 3000 före Kristus skedde nya stora folkvandringar till Europa, närmast havsvägen från främre Östern. Vandringarna gick mot Spanien, Frankrike och Schweiz. De här folken var såväl boskapsuppfödare som jordbrukare. Ungefär år 2000 före Kristus var de marker som gick lättast att odla - det fanns dock inte särskilt mycket sådan jord i Europa - rätt fullt befolkade. Vid denna tid började likväl en ny befolkningsvåg strömma till Europa. Längs Atlantkusten norrut vandrade det för sina dryckeskärl kända stop- eller bägarefolket. Från Sydryssland vandrade västerut det för sina slipade stenyxor kända folk, som också fått sitt namn efter dem, stridsyxfolket, som snabbt bredde ut sig över Europa och idkade jordbruk på sandjorden, som var något kargare än lössjorden. När sedan kelter, germaner och 


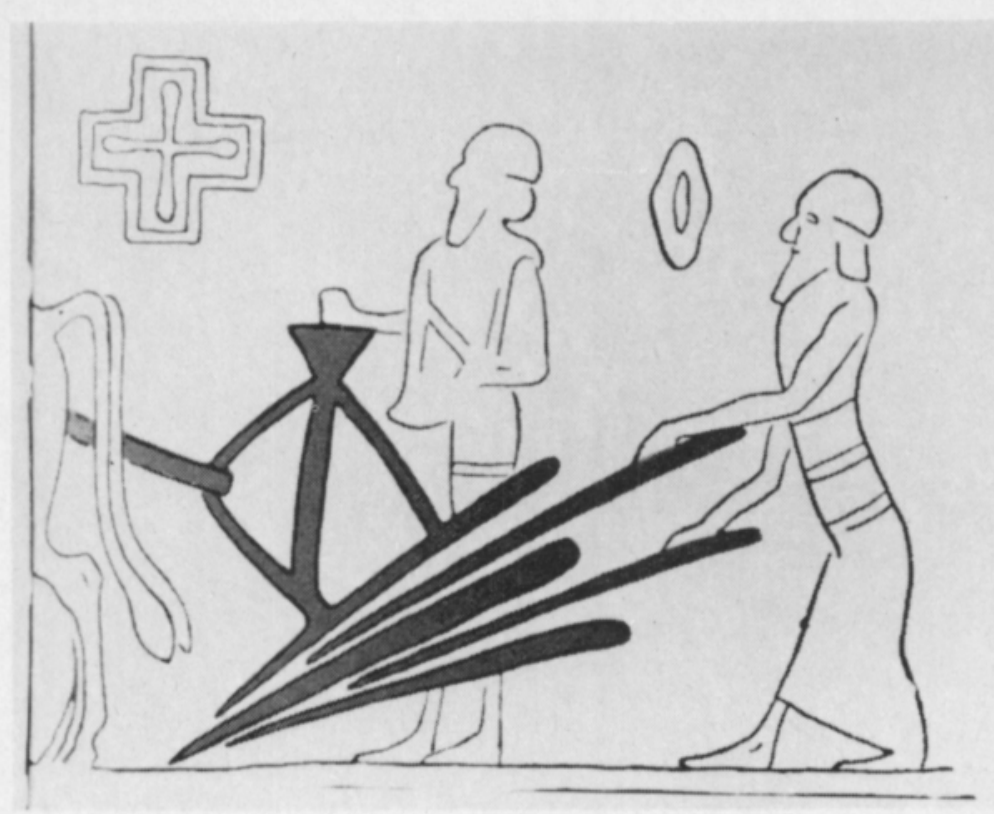

Bild 5. Den äldsta kända bilden av en plog försedd med såddtrattar härstammar från andra förkristliga årtusendet i Kassiternas rike, där Iran nuförtiden ligger.

slaviska folk bredde ut sig till Europa under järnåldern på 1. årtusendet före Kristus, var Europa någorlunda fullständigt befolkat.

Gamla kulturer har hittills, den ena efter den andra, blomstrat och sedan gått under. En orsak till kulturernas undergång har uppenbart ursprungligen varit de begränsningar den omgivande naturen ställt, vilkas betydelse människorna inte har förstått. Vad beror det sedan på att Mellan- och Nordeuropa slutligen upplevat en sådan aldrig förekommen kulturuppgång och ett sådant tekniskt genombrott? Frågan är naturligtvis för omfattande att besvara uttömmande i detta sammanhang, men några synpunkter torde kunna anläggas.

Förutsättningarna för västra Europas snabba utveckling var ingalunda självklar, för t.ex. ännu på 800-talet efter Kristus var området en svårartad "bakskog", där det syntes svårt att finna några framtidslöften. När det Västromerska riket brutit samman, gick de tidigare blomstrande städerna i Mellan-Europa bakåt och minskade också till arealerna. Metallgruvorna verkade tömda. Under nionde århudradet efter Kristus präglades inte ett enda guldmynt i Mellan-Europa. Skandinaverna idkade något handel med Sydeuropa, och England förde ut små mängder tenn, men det övriga Europa, som $\mathrm{i}$ allmänhet var uppdelat i små områden, förmådde endast producera förnödenheter för eget behov.

Vid millennieskiftet vändes i alla fall bladet i Mellan- och Nordeuropas historia. För det första försökte aldrig främmande erövrare efter detta tränga in på området. Vikingarna var redan "tämjda" och deras boplatser blev en del av den europeiska kulturkretsen.

Som tidigare konstaterats har en förutsättning för civilisationens utveckling hittills varit den, att jordbruket förmår producera föda rejält över dess utövares egna behov. Jordbrukets produktivitetstillväxt kom också att bli en central fråga i Mellan- 


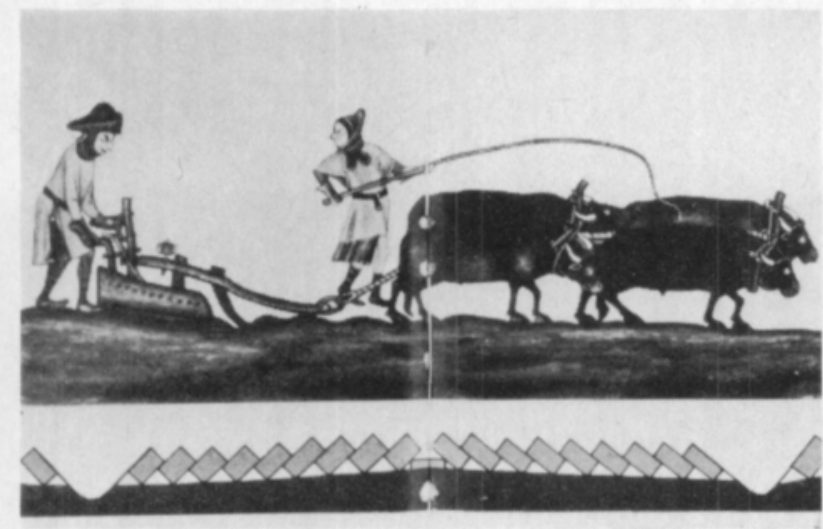

Bild 6. Omkring år 1000 e.Kr. utvecklades en tung vändplog i Europa.

och Nordeuropas utveckling. Mycket viktig var den tidigare omnämnda faktorn, att i den tempererade zonen kunde man förlita sig till naturliga regnmängder.

En kanske avgörande betydelse hade ett tekniskt steg i utvecklingen, nämligen uppfinningen av en ny plogtyp. Medelhavsländernas folk använde fortfarande en plogtyp som härstammade från den torra zonens hydraulsamhällen, och med vars hjälp man blott kunde söndra jordytan. Mellan fårorna förblev alltid orörd mark och därför plöjdes fältet en andra gång vinkelrätt mot de första fårorna. Ảkrarna var vanligen små och kvadratiska. Också i Mellan- och Nordeuropa använde den jordbrukande befolkningen länge liknande metoder som lämpade sig någorlunda väl för de lättbrukade högländerna, men som var helt odugliga i de fuktiga, mycket bördigare dalarna där jorden var seg. På dylika låglänta marker sköljdes också näringsämnena så djupt in i jorden att det var omöjligt att vända upp dem med de tidigare plogarna. Man behövde djupare gående luckring. Problemet löstes när man uppfann en tung vändplog av s.g.s. nuvarande typ. (bild 6). Med dess hjälp kunde Mellan- och Nordeuropas bördiga ådalar och andra lågmarker plöjas upp till åkrar.

Därtill tog man i bruk ett nytt odlingssystem. Medelhavsländernas folk använde sig av ett s.k. två-års kretslopp, i vilket bara halva åkerarealen var samtidigt i bruk. I Medelhavsländerna måste på grund av sommartorkan säden sås på hösten och skördas på våren. Nybyggarna från söder försökte först använda liknande metoder i Mellaneuropa, men råkade ofta ut för svåra besvikelser.

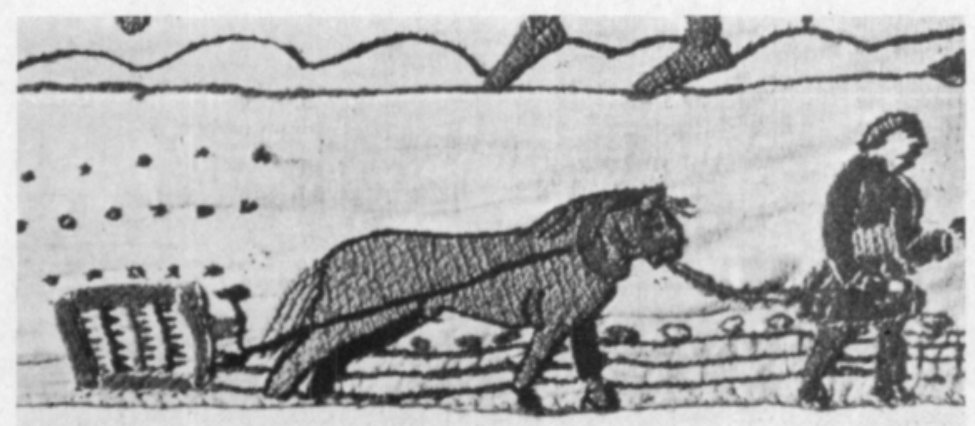

Vild 7. En synnerligen viktig uppfinning var det styva bogträet - uppfinningen härstammar från Turkestan - som ökade hästens dragförmåga 4 . . . S-faldigt i jämförelse med det gamla halsremsystemet. 


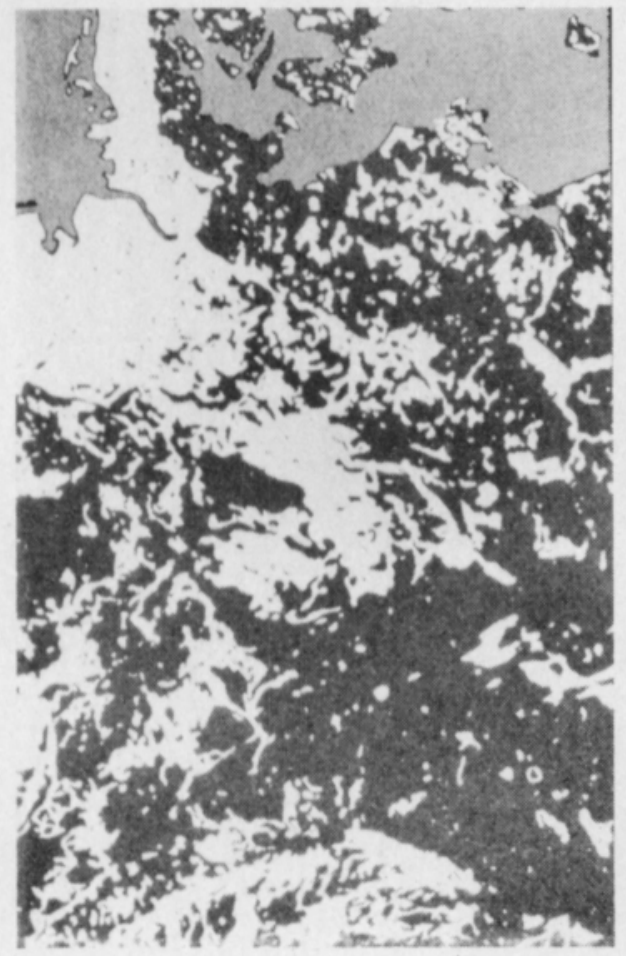

Bild 8. Skogbevuxen mark (de mörka arealerna) i Mellaneuropa år 900 e. Kr.

$\leftarrow$

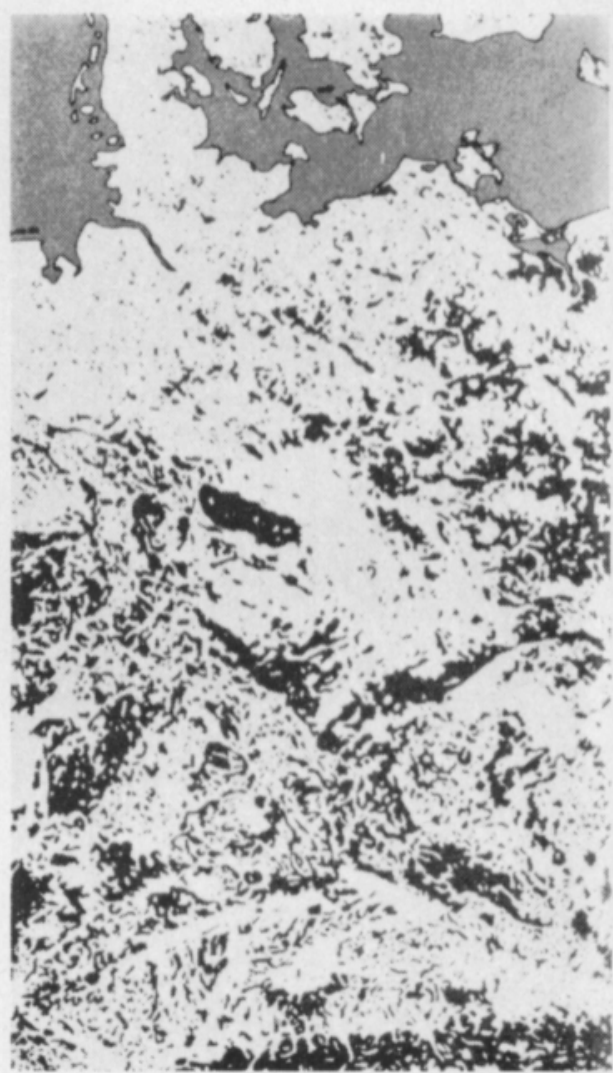
e. Kr.

Det dröjde inte länge förrän norrifrån utbredde sig den av våra kalla vintrar dikterade vanan att så om våren och skörda på hösten. Småningom utvecklades i Mellan- och Nordeuropa också det s.k. treårskretsloppet, där 2/3 av åkerarealen alltid var i bruk. Inom det nya systemet gick det bra att varje år producera havre, som var ett ytterst effektivt hästfoder.

En synnerligen viktig uppfinning var det styva bogträet (bild 7) som ökade hästens dragförmåga t.o.m. 4-5-faldigt i jämförelse med det gamla halsremsystemet. Den här uppfinningen drog naturligtvis också trafiken nytta av, då hästarna kunde dra flere gånger tyngre lass än tidigare. De här nya metoderna var allmänt i bruk i Mellan- och Nordeuropa redan under 11. århundradet. En följd av att byta ut oxarna mot hästar var att bönderna kunde bo på längre avstånd från sina åkrar än tidigare. Sålunda kunde man bosätta sig i större byar, vilket medförde att förutsättningarna för civilisationens utveckling var helt andra än vid glesbebyggelse.

De nya metoderna stegrade pa ett avgörande sätt jordbrukets produktivitet. En föjdverkan var en oerhörd ökning av skogens röjning till odlingsmark (bilderna 8 och 9) en annan åter grundandet av städer och en aldrig tillförne sedd utveckling 


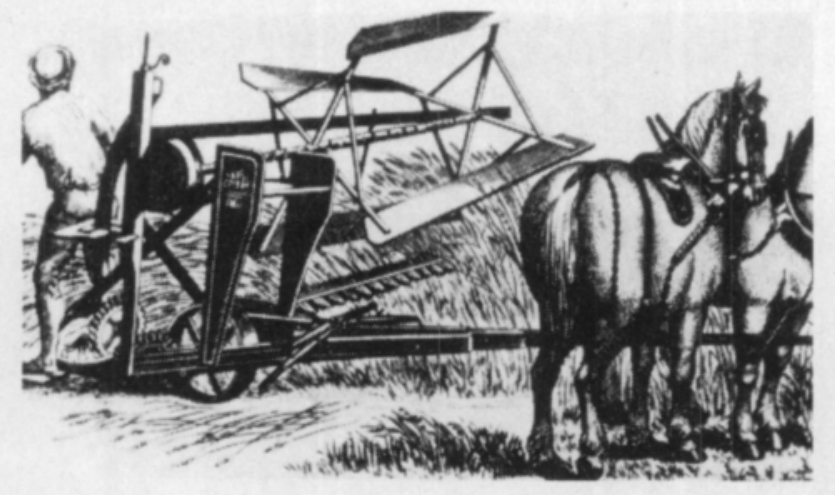

Bild 10. Den första effektiva slåttermaskinen utvecklades år 1831 i Virginia i USA.

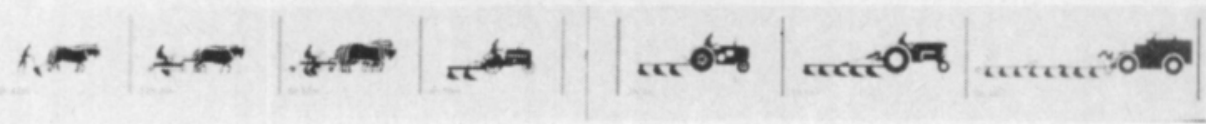

Bild 11. Denna bildserie utvisar, att då det tar $131 / 2$ timmar att plöja en 1 ha stor areal med en vanlig vândplog dragen av två hästar, går det att plöja samma areal på knappt 41/2 timmar med en tvåskärig traktorplog och på endast 40 minuter med en åttaskärig stark traktorplog.

inom handel och handslöjd. Som slutresultat stod i sista hand teknikens och vetenskapens enorma framsteg i ny tid och sedermera det teknologiska genombrottet och den industriella revolutionen.

Den industriella revolutionen möjliggjorde jordbruksteknologins snabba utveckling. Metall blev det rådande materialet för jordbruksredskapen. Maskinkraft togs $\mathrm{i}$ bruk. Jag går inte in på denna utveckling, jag nämner bara några skeden. Den första verkligt effektiva slåttermaskinen utvecklade Cyrus MacCormick år $1831 \mathrm{i}$ Virginia i USA (bild 10). Den första jordbrukstraktorn som gick med ångkraft togs i bruk år 1870. I Amerika började Henry Ford tillverka traktorer med förbränningsmotorer i Detroit år 1907. Mekaniseringen av jordbruksarbetet höjde våldsamt arbetets produktivitet. (bild 11).

Jag återkommer ännu till Pandoras lerkrus. Då människan började röja skog, odla jorden och hålla sig med boskap, öppnade hon locket till Pandoras krus, och det har hon sedan ännu flera gånger gläntat på när hon byggt städer, vägar och trafikmedel. Ur kruset har alltid flugit ut obevekliga fiender, av dem kanske som de ofarligaste ogräsen och som de farligaste skadeinsekterna och framför allt olika sjukdomsalstrare.

Saken belyses av ett forskningsresultat om skadegörare på säd från Kasakstan i Sovjetunionen. Där har mycket stäpp pljöts upp till veteodlingar. Före plöjningen konstaterades på den orörda stäppen i medeltal 200 individer på en kvadratmeters yta och i forskningsområdet upphittades i allt 330 insektarter. När stäppen hade varit veteåker en tid, fann man i medeltal 350 insektindivider per kvadratmeter. De tillhörde endast 19 arter, av vilka de flesta var svåra skadegörare på vete. I de nya förhållanden som skapats av människan, hade de få arter som kunde tillgodogöra sig vete som föda ökat i förvånande grad. Vid stark population kan skadeinsekterna på ett avgörande sätt minska skörden av säd och andra odlingar. Därför har man redan länge försökt finna på effektiva skyddsämnen, vilka dock i sin tur, i synnerhet under senaste tid, har medfört nya problem, även teknologiska.

Må vi dock minnas, att i Pandoras lerkrus blev hoppet kvar. 


\section{Litteratur}

MAKKONEN, Olli, 1971. Miten ihminen on muuttanut luontoa. "Universitas", No 11.17 p. Porvoo. RUSSELL, W.M.S. 1967. Man, Nature and History. Aldus Books. London.

Ms received April 6, 1981.

\section{SELOSTUS}

\section{Maatalousteknologian kehityksen historiallisia päälinjoja.}

\section{Olli Makkonen}

Helsingin yliopisto, Kansantaloudellisen metsäekonomian laitos, Unionink. 40 B, 00170 Helsinki 17

Ihmisen puusta maahan siirtymisen jälkeen omaksuma pystyasento, joka teki mahdolliseksi lyömäaseiden ja tyôvälineiden käytön, oli ensimmäinen askel kohti maapallon herruutta, mutta vielä ratkaisevampi tekijā oli tulen kāyttōōn otto (salaman sytyttämistä kuloista, tulivuorenpurkauksista) ja varsinkin tulentekotaidon keksiminen, mikã mahdollisti alkeellisimman maanviljelyksen muodon, kaskiviljelyn kehittymisen.

Pysyvään maanviljelykseen ryhtyminen on ollut eräs ihmisen historian ratkaisevimpia kãännekohtia. Kaiken kehityksen ja sivilisaation edellytyksenã on ravinnon ylijäämä, ja sen aikaansaaminen on ollut mahdollista vasta pysyvään maanviljelykseen siirtymisen jälkeen. Pysyvã maanviljelys syntyi ns. kuivalla vyöhykkeellã suurten, koskaan kuivumattomien jokien (Niili, Kaksoisvirrat, Indus ym.) tuntumassa ja perustui alunperin keinokasteluun. Härkien vetãmä, maan pintaa möyhentävä aura tuli käyttöön jo kolmannella vuosituhannella e. Kr. sekä Kaksoisvirranmaassa ettã Egyptissã.

Keski- ja Pohjois-Euroopan sivilisaation nopea edistyminen n. vuodesta 1000 j.Kr. lähtien sekä pitkällä tähtãyksellä lopuksi tekniikan läpimurto ja teollinen vallankumous perustuivat pohjimmiltaan kolmeen tärkeãän tekijään. Ensinnäkin lauhkealla vyōhykkeellã voitiin maanviljelyksessã melko turvallisesti jättäytyã luonnon suoman sateen varaan, mikä ratkaisevasti vähensi maanviljelyksen vaatimaa työmäärää keinokasteluun perustuvaan viljelyyn verrattuna. Toiseksi keksittiin lähes nykyisen tyyppinen raskas kääntöaura, jolla Euroopan viljavat, mutta sitkeäpohjaiset joki- ja muut laaksot saatiin kynnetyiksi pelloiksi. Kolmanneksi keksittiin jäykät puiset länget, jotka nostivat hevosen vetokyvyn 4-5 kertaiseksi entiseen kaulahihnasysteemiin verrattuna. Kun härät korvattiin paljon nopeammilla hevosilla, voitiin asua entistä kauempana pelloilta yhteisissä kylissä, jolloin sivilisaation edellytykset huomattavasti lisääntyivät.

Uudet menetelmät paransivat ratkaisevasti maatalouden tuottavuutta. Seurauksina olivat metsänraivauksen tavaton lisääntyminen, kaupunkien perustaminen sekä kaupan ja käsiteollisuuden ennen näkemätön kehitys. Tekniikka ja tieteet edistyivät uudella ajalla valtavasti, mikä johti lopulta teknologian läpimurtoon ja teolliseen vallankumoukseen.

Teollinen vallankumous mahdollisti lopuksi maanviljelystöiden koneellistamisen ja tuottavuuden kohoamisen ennen aavistamattomassa määrin. 